\title{
Glucocorticoid-Mediated Repression of REDD1 mRNA Expression in Rat Fetal Distal Lung Epithelial Cells
}

\author{
GAIL OTULAKOWSKI, WENMING DUAN, APARNA SARANGAPANI, SHEPHALI GANDHI, AND HUGH O'BRODOVICH
}

\begin{abstract}
CIHR Group in Lung Development [G.O., W.D., A.S., S.G., H.O.], Hospital for Sick Children Research Institute, Toronto, Ontario, M5G
\end{abstract} 1X8, Canada; Department of Paediatrics [G.O., H.O.], University of Toronto, Toronto, Ontario, M5G 1X8, Canada

\begin{abstract}
REDD1 (Regulated in Development and DNA Damage-1) is a stress-response gene that represses mammalian target of rapamycin (mTOR) thus decreasing protein synthesis. In contrast to studies using cell lines and adult alveolar type II (ATII) cells, we find that REDD1 mRNA levels did not increase in rat fetal distal lung epithelia (FDLE) or fetal lung fibroblasts grown in primary cultures and then exposed to $3 \% \mathrm{O}_{2}$. REDD1 mRNA expression was repressed by dexamethasone (DEX) in FDLE and ATII, but induced by DEX in fibroblasts. Lung epithelial cell lines, A549 and MLE-15, showed increases in REDD1 mRNA in response to hypoxia and DEX. The effect of DEX on REDD1 mRNA and protein in FDLE and fibroblasts was dose- and time-dependent. Inhibitor studies support repression of REDD1 mRNA by DEX in FDLE was mediated via glucocorticoid receptor and not by nongenomic effects of glucocorticoids via MAPK pathways. The half-life of REDD1 mRNA was shorter in DEX-exposed FDLE compared with hormone-free media suggesting that DEX reduced REDD1 mRNA stability in FDLE. These studies indicate that REDD1 expression in response to hypoxia and DEX is cell-type specific and that physiologically appropriate levels of $\mathrm{PO}_{2}$ should be used when investigating fetal lung development. (Pediatr Res 65: 514-519, 2009)
\end{abstract}

$\mathrm{G}$ lucocorticoid (GC) hormones are catabolic and affect both protein synthesis and degradation in many mammalian tissues, particularly in lymphoid tissues and skeletal muscle (1). In the lung, dexamethasone (DEX) has been shown to decrease protein synthetic rates by attenuating mRNA translation at two levels: translational efficiency (i.e. translation initiation) and translational capacity (i.e. ribosome biogenesis) (2). Because GC are used extensively to promote fetal lung maturation in women in preterm labor (3) and to treat a variety of acute and chronic lung conditions such as asthma, chronic obstructive pulmonary disease (4), and respiratory distress syndrome (5), it is essential that we develop an improved understanding of how individual lung cell types respond to GC exposure.

Received October 1, 2008; accepted December 1, 2008.

Correspondence: Gail Otulakowski, Ph.D., Program in Physiology and Experimental Medicine, Hospital for Sick Children Research Institute, 555 University Avenue, Toronto, Ontario, Canada M5G 1X8; e-mail: gail.otulakowski@sickkids.ca

Supported by Grant MGP-25046 from the Canadian Institutes of Health Research Operating and from a Group Grant in Lung Development.

Current address (H.O.): Department of Pediatrics, Stanford School of Medicine, Stanford, CA 94305.
GC exposure attenuates mRNA translation by a variety of signal transduction mechanisms (6), including decreased phosphorylation of the ribosomal protein S6 kinase (p70S6 K) and of the eukaryotic initiation factor (eIF)-4E-binding protein (4E-BP) (7). The serine-threonine kinase, mammalian target of rapamycin (mTOR) is a central integrator of environmental signals, including nutrients, growth factors, hormones, and hypoxia, and mTOR promotes mRNA translation by phosphorylating p70S6 K and 4E-BP (8). Recent publications have provided evidence that the protein encoded by REDD1 (Regulated in Development and DNA damage responses) may play a critical role in linking a variety of cues, including hypoxia and GC treatment, to inhibition of translation via the mTOR pathway (9-11). DEXmediated induction of REDD1 transcription has been demonstrated in lymphoid cells (12) and in skeletal muscle in vivo and L6 myoblasts (10). In contrast, numerous publications have shown REDD1 mRNA is induced via hypoxia inducible factor-1 (HIF-1) (13) in a variety of cultured cell lines $(11,14)$.

During gestation, the developing fetus is exposed to increases in circulating cortisol which are important for maturation of the lung (15). In addition, the fetal lung experiences rather low $\mathrm{O}_{2}$ tension $\left(3 \% \mathrm{O}_{2}\right)$ relative to the postnatal lung $\left(21 \% \mathrm{O}_{2}\right)$. Both $\mathrm{PO}_{2}$ and $\mathrm{GC}$ have been demonstrated to be important regulators of fetal lung maturation (16). We recently showed that a combination of fetal $\mathrm{O}_{2}$ levels and DEX inhibited mTOR signaling in primary cultures of rat fetal distal lung epithelia (FDLE), yet this was not associated with increased expression of REDD1 in response to hypoxia and GC as would be predicted (17). Surprisingly, REDD1 was unresponsive to $\mathrm{PO}_{2}$ and was repressed by $50 \mathrm{nM}$ DEX.

In addition to direct transcriptional activation of target genes by binding of the activated glucocorticoid receptor (GR) to its response element, GC signaling can also reduce expression of specific genes either by direct binding to negative glucocorticoid response elements, by modulating the effects of other transcription factors such as NF- $\kappa \mathrm{B}$, or via posttranscriptional and nongenomic actions including pathways controlling mRNA stability $(6,18)$.

\footnotetext{
Abbreviations: ATII, adult type II alveolar epithelial cells; DEX, dexamethasone; FDLE, fetal distal lung epithelium; GC, glucocorticoid; GR, glucocorticoid receptor; HIF-1, hypoxia inducible factor-1; mTOR, mammalian target of rapamycin; REDD1, regulated in development and DNA damage- 1
} 

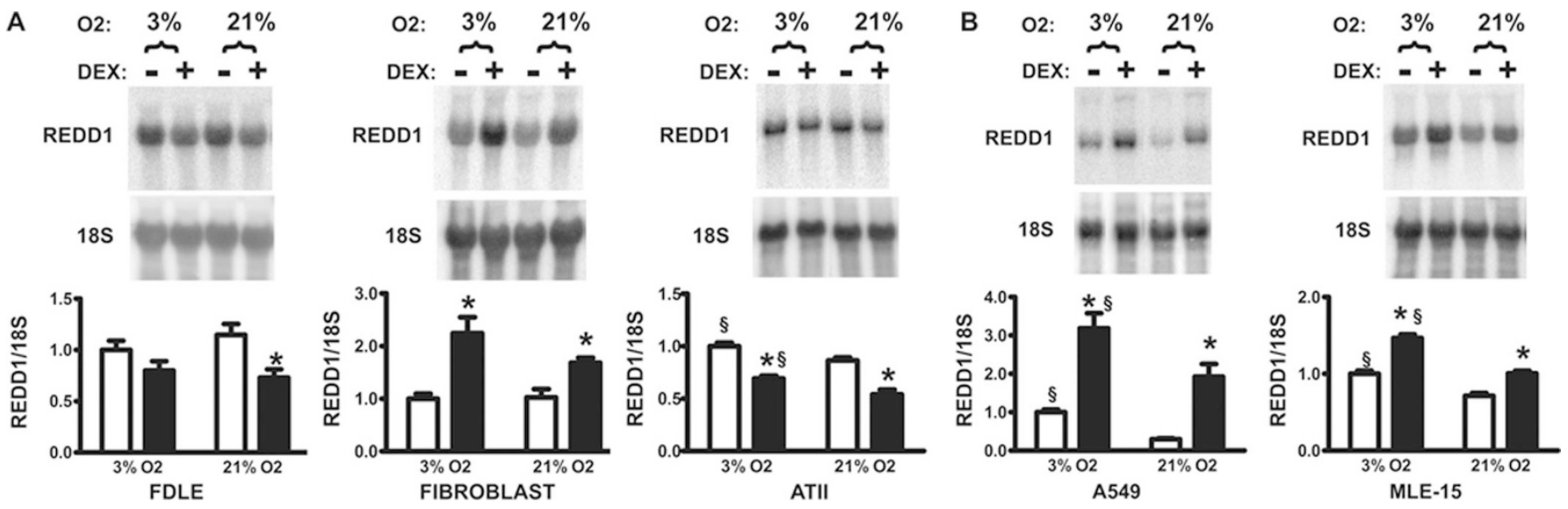

Figure 1. Expression of REDD1 mRNA in response to $\mathrm{PO}_{2}$ and DEX. (A) Representative Northern blots and quantitation from rat primary cultures of FDLE, fetal lung fibroblasts and ATII cells are shown. $(B)$ Representative Northern blots and quantitation from A549 and MLE-15 are shown. Data are presented as mean \pm SEM, $n=5-8$ samples from three independent experiments. $\square$ : hormone-free media. $\square$ : media $+50 \mathrm{nM}$ DEX. * $p<0.05$ relative to hormone-free condition; $\$ p<0.05$ relative to $21 \% \mathrm{O}_{2}$.

We hypothesized that regulation of REDD1 mRNA expression in response to $\mathrm{PO}_{2}$ and DEX was distinct in the developing lung. We conducted experiments in primary cultures of rat FDLE and their adjacent lung fibroblasts, in adult rat alveolar type II epithelial cells (ATII) and in lung epithelial cell lines.

\section{MATERIALS AND METHODS}

Cell isolation and culture. Primary cultures of FDLE and their adjacent fibroblasts were obtained from 20-d timed gestation rat fetuses by enzymatic digestion, centrifugation, and differential adherence as previously described (19). ATII cells were isolated from 100-200 g male Sprague Dawley rats by enzymatic digestion and purified based on differential adherence of cells to dishes coated with rat $\operatorname{IgG}(20)$. All animal procedures were approved by the Hospital for Sick Children Animal Care committee. Cells were grown in DMEM-glucose $(4.5 \mathrm{~g} / \mathrm{L}$ glucose with $2 \mathrm{mM} \mathrm{L}$-glutamine and $110 \mathrm{mg} / \mathrm{L}$ sodium pyruvate) supplemented with $10 \%$ FCS (FCS, Cansera, Rexdale, Ontario), $100 \mathrm{U} / \mathrm{mL}$ penicillin G sodium and $100 \mu \mathrm{g} / \mathrm{mL}$ streptomycin sulfate. Culture media was replaced $24 \mathrm{~h}$ after seeding of FDLE ( $48 \mathrm{~h}$ for ATII) to remove unattached cells, at which time media containing hormone-depleted FCS (stripped with charcoal and ion exchange resin) was used, supplemented as indicated with DEX, RU486 (Sigma Chemical, Oakville, ON, Canada), or SB203580 (Calbiochem, San Diego, CA) and cells were placed in incubators containing either $3 \% \mathrm{O}_{2}-5 \% \mathrm{CO}_{2}$-balance $\mathrm{N}_{2}$ ("fetal" atmosphere) or $5 \%$ $\mathrm{CO}_{2}$-balance room air ("postnatal" atmosphere) for up to $48 \mathrm{~h}$.

Lung epithelial cell lines (A549 and MLE-15) were obtained from the American Type Culture Collection and grown to confluence in "postnatal" atmosphere, after which media was changed as above for FDLE and cells were allocated to "fetal" or "postnatal" incubators for $48 \mathrm{~h}$.

RNA isolation and northern blot hybridization. Total cellular RNA was extracted using TRIzol reagent (Invitrogen, Burlington, ON, Canada). Gel electrophoresis was performed using $10 \mu \mathrm{g}$ of RNA per sample on a $1 \%$ agarose $2.2 \mathrm{M}$ formaldehyde gel in $1 \times$ MOPS (3-morpholinepropanesulfonic acid) buffer (20 mM MOPS pH7.0, $5 \mathrm{mM}$ sodium acetate, $1 \mathrm{mM}$ EDTA) and transferred to Hybond- ${ }^{+}$membrane. Membranes were hybridized in Expresshyb solution (Clontech, Palo Alto, CA) at $65^{\circ} \mathrm{C}$ using ${ }^{32} \mathrm{P}-$ labeled random primed cDNA probes for REDD1. Hybridized membranes were washed at high stringency and analyzed using a STORM PhosphorImager equipped with ImageQuant software (Molecular Dynamics, GE Healthcare, Baie d'Urfe, QC, Canada). The mRNA levels were normalized to $18 \mathrm{~S}$ ribosomal RNA.

Western blots. Tissue culture dishes on ice were washed twice with ice-cold PBS and lysed by direct addition of RIPA buffer $(150 \mathrm{mM} \mathrm{NaCl} ; 20$ $\mathrm{mM}$ Tris $\mathrm{pH} 8 ; 0.1 \%$ SDS; $1 \%$ TritonX-100; $0.5 \%$ sodium deoxycholate; $1 \times$ Roche complete protease inhibitor cocktail (Roche Applied Science, Laval, QC, Canada). Proteins ( $50 \mu \mathrm{g})$ were size fractionated on SDS-PAGE gels and transferred to nitrocellulose. After blocking using 5\% nonfat dry milk in PBS supplemented with $0.05 \%$ (wt/vol) TritonX-100, membranes were incubated $1 \mathrm{~h}$ with 1:1000 dilution of rabbit polyclonal antibody against REDD1 (ProteinTech Group, Chicago, IL) and washed several times in PBS. Second- ary antibody was diluted 1:40,000 and incubated for $1 \mathrm{~h}$ at room temperature. All further washes were in PBS with $0.05 \%$ TritonX-100. ECL detection reagents were from GE Healthcare (Baie d'Urfé, QC, Canada). Blots were blocked and probed for actin, according to standard protocols.

RNA stability assay. FDLE or fibroblasts were seeded and cultured as described in the presence or absence of $50 \mathrm{nM}$ DEX for $48 \mathrm{~h}$. Transcription was stopped by addition of $5 \mu \mathrm{g} / \mathrm{mL}$ actinomycin D (VWR Canlab, Mississauga, ON, Canada) and cells were harvested at different time points $(0,0.5$, 1,2 , and $3 \mathrm{~h}$ ). RNA was isolated and analyzed by Northern blot hybridization. REDD1 mRNA half-life was calculated using GraphPad Prism version 4.0 (GraphPad Software, San Diego, CA) using a one-phase exponential decay model.

Statistical analysis. Data are presented as mean \pm SEM. Statistical significances were calculated using one-way ANOVA followed by Tukey post test with $p<0.05$ being considered as statistically significant. Two-way ANOVA followed by Bonferroni post-test was used to compare effects of DEX over time in the time course experiments. Statistical analysis was performed using GraphPad Instat version 3.01 and GraphPad Prism version 4.0.

\section{RESULTS}

Effects of oxygen and DEX on REDD1 mRNA expression in distal lung cells and cell lines. Our previous study (17) showed that when primary cultures of FDLE were exposed to different $\mathrm{PO}_{2}$ levels, there was no significant effect on REDD1 mRNA or protein, and that $50 \mathrm{nM}$ DEX treatment decreased, rather than increased, the REDD1 expression. This study (Fig. $1 A)$ confirmed these results and showed that primary cultures of the adjacent fetal lung fibroblasts also failed to respond to changes in $\mathrm{PO}_{2}$. Primary cultures of ATII cells, in contrast, showed a statistically significant increase in REDD1 mRNA expression under $3 \% \mathrm{O}_{2}$. Fetal lung fibroblast cultures responded differently from the two epithelial cultures to DEX, showing a significant increase in REDD1 mRNA after a 48-h treatment with $50 \mathrm{nM} \mathrm{DEX}$, in both fetal (3\%) and postnatal (21\%) $\mathrm{O}_{2}$ atmospheres (Fig. 1A). Although published studies reported that hypoxia induced REDD1, we noted that the experimental protocols used severe hypoxia $\left(\leq 1 \% \mathrm{O}_{2}\right)$ and usually used transformed or cancer-derived cell lines. Accordingly, we examined whether $3 \% \mathrm{O}_{2}$ was sufficiently hypoxic to induce REDD1 in the A549 cell line (human lung carcinoma), and the murine transformed cell line, MLE-15 (Fig. $1 B)$. Steady-state levels of REDD1 mRNA were significantly 

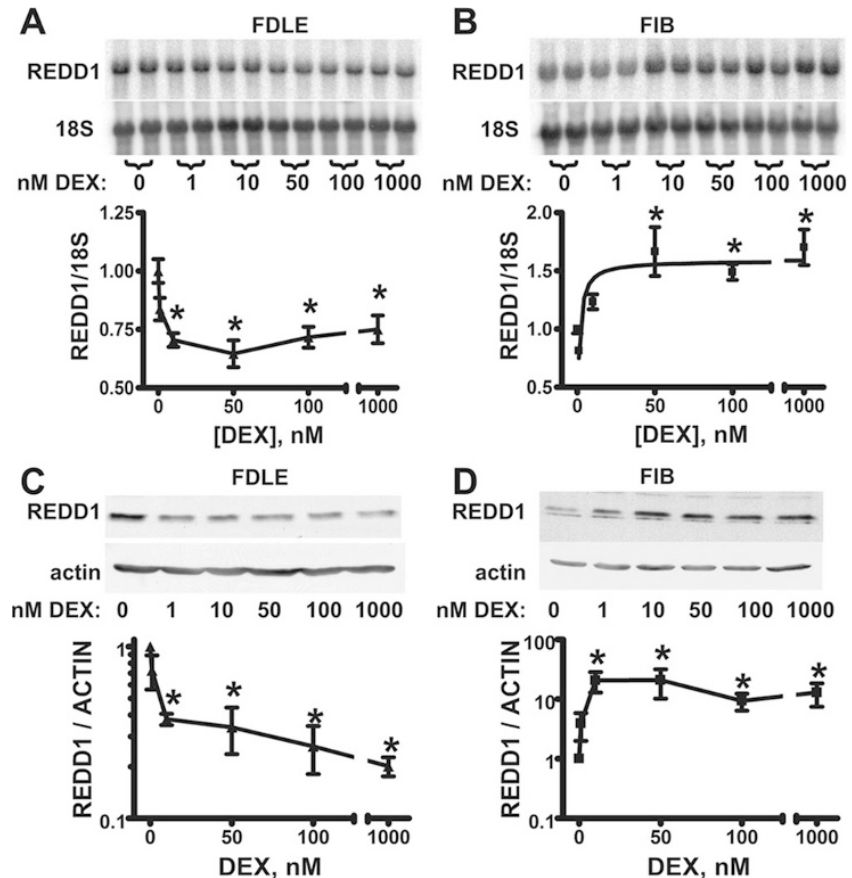

Figure 2. Dose response of DEX-mediated regulation of REDD1 in primary cultures of fetal lung cells. Representative Northern blots and quantitation of REDD1mRNA in Northern blots from rat FDLE $(A)$ or fibroblasts $(B$, FIB) are shown. Western blots and quantitation of REDD1 protein in lysates from FDLE $(C)$ and fibroblasts $(D)$ treated with various concentrations of DEX confirm that protein levels correlate with changes induced in mRNA levels. Results are expressed as mean \pm SEM relative to expression in hormone-free cultures, $n=5-7$. $* p<0.05$ relative to control ( $0 \mathrm{nM}$ DEX).

increased in 3\% $\mathrm{O}_{2}$ in both A549 and MLE-15 epithelia. Both cell lines also exhibited increased REDD1 mRNA levels in response to $50 \mathrm{nM}$ DEX with $3 \% \mathrm{O}_{2}$ and DEX showing additive effects. Because neither FDLE nor primary lung fibroblasts showed changes in REDD1 mRNA in response to changes in $\mathrm{PO}_{2}$, the remaining experiments were carried out in primary fetal cells cultured under $21 \% \mathrm{O}_{2}$.

Dose-dependent effect of DEX on REDD1 mRNA expression. To determine whether higher pharmacological doses of DEX could increase REDD1 mRNA levels in FDLE, we exposed FDLE cells to increasing DEX concentrations (Fig. 2A). DEX at low doses depressed basal expression of REDD1 reaching minimum expression at $50 \mathrm{nM}$, after which the REDD1 level had a nonsignificant trend to increase, which did not return to basal levels. In contrast, treatment of primary lung fibroblasts with increasing concentrations of DEX (Fig. 2B) showed a statistically significant increase in REDD1 when fibroblasts were exposed to doses of DEX greater than $1 \mathrm{nM}$. This effect of DEX reached a plateau at concentrations $\geq 50 \mathrm{nM}$. Western blots to detect REDD1 protein levels in FDLE (Fig. 2C) and fibroblasts (Fig. 2D) indicated that changes in REDD1 protein closely followed the shapes of the mRNA dose response curves, although the magnitude of the changes appears larger at the protein level (note the $\log$ scale on the $y$-axes in parts $C$ and $D$ ).

Time course of DEX effects on REDD1 mRNA expression. REDD1 expression has been reported to be influenced by cell density in cultured cells, with increased REDD1 in HeLa and

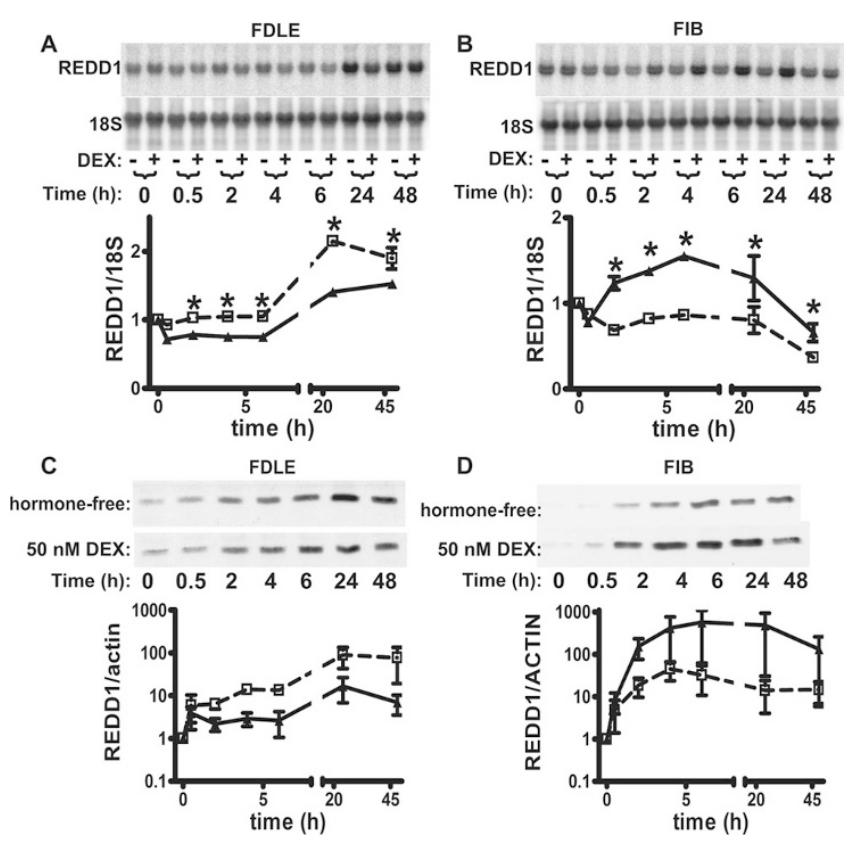

Figure 3. Time course of DEX-mediated effects on REDD1 in primary cultures of fetal lung cells. Representative Northern blots and quantitation from $(A)$ FDLE and $(B)$ fibroblasts. $\square$ : hormone-free media. $\mathbf{\Delta}$ : media +50 nM DEX. * indicates $p<0.05$ when comparing DEX $v s$ hormone-free. Quantitative data are presented as mean \pm SEM, $n=6-8$ samples from 3-4 independent experiments. Representative Western blots of REDD1 protein from FDLE $(C)$ and fibroblasts $(D)$. Both time $(p<0.0001)$ and DEX $(p=$ 0.0334 ) were significant effects in FDLE by quantitated Western data. Only time $(p<0.001)$ effect reached significance in fibroblasts, under hormonefree and DEX condition. Data are presented as mean \pm SEM, $n=3$.

293T cells at high compared with low cell density, and this effect, like hypoxia, appeared to be mediated transcriptionally via HIF-1 (21). Because GC can decrease cell proliferation, we questioned whether cell density could be a confounding factor in our results. We examined the time course of REDD1 expression in both FDLE and fibroblasts after treatment with DEX. Cells were visually $95-100 \%$ confluent when DEX treatment was initiated and fully confluent by $24 \mathrm{~h}$. FDLE are contact inhibited and do not proliferate after the monolayer reaches confluence. In FDLE cultured in hormone-free media (Fig. 3A), time in culture had a significant effect on REDD1 expression with increased levels at 24 and $48 \mathrm{~h}$ compared with $t=0 \mathrm{~h}$. However, DEX-mediated repression of REDD1 was apparent earlier, within $2 \mathrm{~h}$ of exposure to agonist, and was maintained throughout the time course. In fibroblast cultures (Fig. 3B), the DEX-induced increase in REDD1 expression was similarly apparent within $2 \mathrm{~h}$ of initiating agonist, and levels of REDD1 remained higher in DEX-treated than in hormone-free fibroblast cultures throughout the time course. REDD1 protein levels were assessed by Western blot (Fig. 3C and $D$ ) over parallel time courses, demonstrating comparable changes in protein and mRNA, with the exception that REDD1 protein persisted in fibroblasts at $48 \mathrm{~h}$ when REDD1 mRNA decreased.

Effect of DEX on REDD1 mRNA stability. Decreased steady-state levels of REDD1 mRNA in FDLE exposed to DEX could be due to either decreased transcription or increased degradation. We determined the stability of REDD1 

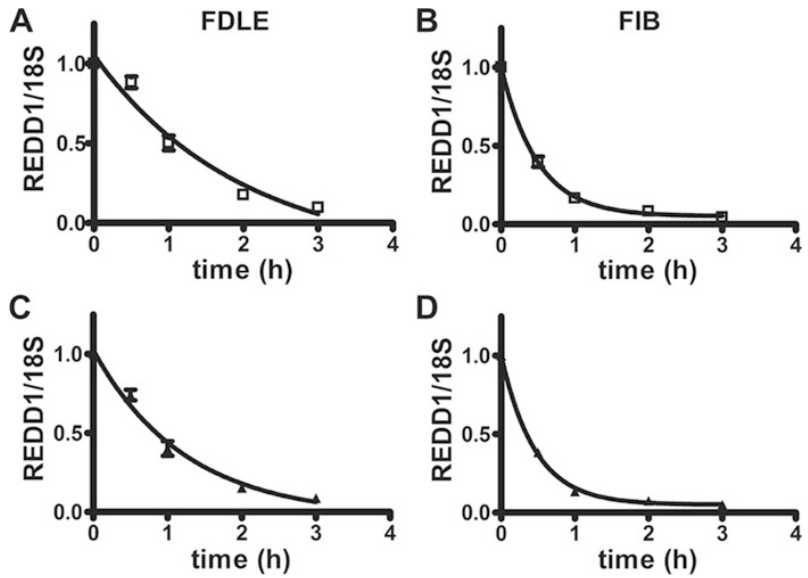

Figure 4. DEX decreases the stability of REDD1 mRNA in FDLE but not in fibroblasts. REDD1 mRNA decay after actinomycin D treatment in FDLE ( $A$ and $C$ ) and fibroblasts $(B$ and $D, \mathrm{FIB})$. Half-life $\left(T_{1 / 2}\right)$ was calculated by nonlinear curve-fit using an equation for one-phase exponential decay. Data are presented as mean $\pm \mathrm{SEM}, n=6$ samples from three independent experiments. $\square$ : hormone-free media. $\mathbf{\Delta}$ : 50-nM DEX.

mRNA in FDLE and lung fibroblasts that were cultured with or without $50 \mathrm{nM}$ DEX and then treated with actinomycinD. The disappearance of REDD1 mRNA over time was quantified relative to $18 \mathrm{~S}$ rRNA and fitted to a one-phase exponential decay model. In FDLE, REDD1 mRNA was significantly less stable in the presence of DEX $\left(T_{1 / 2}=0.86 \pm 0.13\right.$ versus $1.4 \pm 0.05 \mathrm{~h}$ in hormone free media, $p<0.01$, Fig. $4 A$ and $C$ ). This represents an $\sim 40 \%$ decrease in mRNA stability, comparable to the decrease in steady-state REDD1 mRNA level. In contrast, the $T_{1 / 2}$ of REDD1 mRNA was significantly less in fibroblasts than in FDLE under either condition $\left(T_{1 / 2}=0.32 \pm 0.017\right.$ in DEX and $0.34 \pm 0.019 \mathrm{~h}$ in hormone free media, $p<0.01$ versus FDLE, $n=6$ samples from three experiments) and was not affected by DEX treatment.

Effects of inhibitors of glucocorticoid receptor versus $p 38$ MAPK. The effects of DEX on REDD1 mRNA expression in FDLE could be blocked by the specific GR antagonist RU486 at both moderate $(50 \mathrm{nM})$ and high $(1000 \mathrm{nM})$ DEX doses (Fig. 5A), demonstrating that the down-regulation of REDD1 is mediated exclusively via the GR even at extremely high agonist concentrations. Because GC have been shown to induce MAPK phosphatase to block MAPK activity (22), it was hypothesized that MAPK signaling may be involved in the phenomenon. Although GC can inhibit both p38 MAPK and ERK1/2, ERK signaling is up-regulated during cellular proliferation. Our experiments used cultures very near or at confluence at the beginning of the GC treatment. Proliferation in FDLE ceases at confluence, as they are contact inhibited; hence, a role for ERK1/2 seems unlikely. In addition, p38 MAPK is involved in the regulation of mRNA stability via AU-rich elements in mRNA's 3'UTRs, whereas there is little evidence suggesting that ERK plays such a role except in combination with p38MAPK (23). Accordingly, we treated FDLE with either DEX or the p38 MAPK inhibitor SB203580 and assessed REDD1 mRNA levels after 4 and $24 \mathrm{~h}$. Inhibition of p38 MAPK over this time period neither altered REDD1 levels compared with control condition, nor mimicked the effects of DEX treatment.
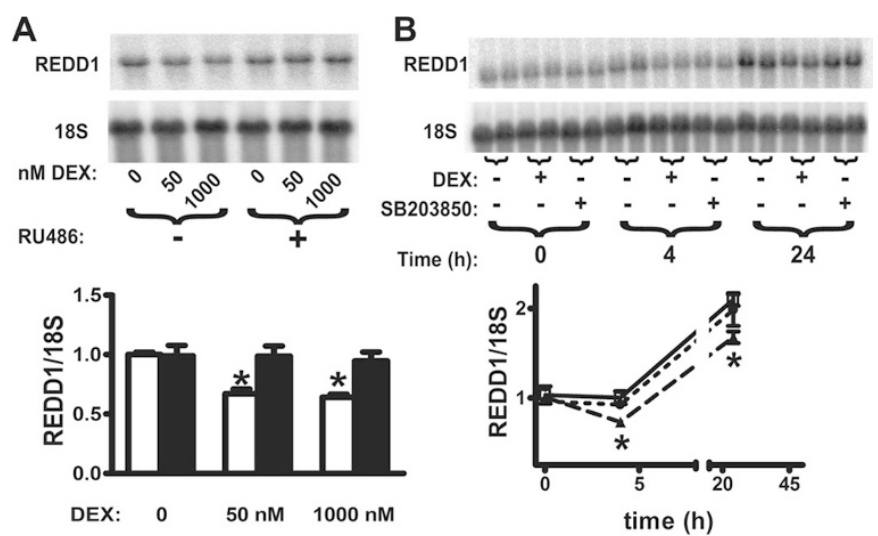

Figure 5. DEX effect on REDD1 in FDLE is mediated via the glucocorticoid receptor, not MAPK pathways. (A) DEX-mediated repression of REDD1 mRNA in FDLE is blocked by the GR antagonist RU486. White bar: control. Black bar: $20 \mu \mathrm{M}$ RU486. ${ }^{*} p<0.05$ relative to control (0 nM DEX). In $(B)$, inhibition of MAPK with SB203580 does not mimic the effect of DEX on REDD1 mRNA expression in FDLE. $\square$ : hormone-free media. $\mathbf{\Delta}$ : media +50 nM DEX. - $2.5 \mu \mathrm{M}$ SB203580. ${ }^{*} p<0.05$ when comparing DEX $v s$ hormone-free.

\section{DISCUSSION}

REDD1 is a transducer of the cellular response to a variety of stresses through the mTOR pathway, generally resulting in a decrease in translation initiation and protein synthesis. Our results demonstrate that modulation of REDD1 expression in response to $\mathrm{PO}_{2}$ and DEX is cell-type specific. Although REDD1 mRNA has been shown to be up-regulated by hypoxia in a HIF-1 dependent manner (14), we show that such up-regulation does not occur in primary cultures of FDLE or fetal lung fibroblasts cultured in $3 \% \mathrm{O}_{2}$ versus $21 \% \mathrm{O}_{2}$. Although the physiologic "fetal" atmosphere we used has a higher $\mathrm{PO}_{2}$ than published reports studying the effects of hypoxia on the induction of $\operatorname{REDD} 1(11,13,14)$, it was sufficient to up-regulate REDD1 in human (A549) and mouse (MLE-15) lung epithelial cell lines and in primary cultures of adult ATII cells. It has also been previously demonstrated that this physiologic fetal $\mathrm{O}_{2}$ atmosphere is sufficient to upregulate HIF-1 in cultured FDLE (24).

The regulation of mRNA translation when cells are exposed to changes in ambient $\mathrm{PO}_{2}$ is critical to our understanding of how cells prevent loss of energy homeostasis under hypoxic conditions. Severe hypoxia (i.e. $1 \% \mathrm{O}_{2}$ ) may be relevant to understanding cancers; however, to understand normal fetal lung growth and development, it is important to use the physiologically relevant level of $\mathrm{PO}_{2}$ on lung cells grown in primary culture. Although precise roles for oxygen-sensing mechanisms in the fetus have not been clearly defined, fetal and perinatal oxygen tensions influence both lung morphogenesis and the perinatal transition from fluid secretion to fluid absorption, essential for a successful transition of the infant to an independent, air-breathing existence (25). It is understood that acute versus prolonged hypoxia results in changes in mRNA translation regulated by distinct mechanisms of translational control, only some of which are HIF-1 dependent (26). It is possible that the lack of up-regulation of REDD1 in FDLE in response to $3 \% \mathrm{O}_{2}$ represents an important characteristic of these cells to permit the very 
high rates of protein synthesis required for normal fetal growth in the uterine environment. Our observation that ATII cells upregulate REDD1 mRNA in response to fetal $\mathrm{O}_{2}$ concentration is consistent with such an adaptation being specific to fetal cells to prevent growth retardation under the developmentally appropriate $3 \% \mathrm{O}_{2}$ environment.

DEX produced opposite effects on REDD1 expression in FDLE and lung fibroblasts even though both were obtained from the same fetuses and grown in primary culture. Although DEX induced REDD1 in fibroblasts, similar to results published in lymphoid cells and myoblasts, in FDLE DEX exerted a repressive effect. Kimball et al. (27) recently demonstrated rapid protein degradation as a regulatory mechanism controlling REDD1 expression when translation elongation and mTOR signaling are inhibited by cycloheximide. However, we found that DEX-mediated changes in REDD1 mRNA and protein levels are well correlated indicating that DEX effects were mediated at the RNA level.

The expression of REDD1 has been reported to be affected by cell density (21). Both FDLE and fibroblasts were fully confluent at the time of harvest for REDD1 mRNA analysis; however, we also examined REDD1 mRNA steady-state levels during the $48 \mathrm{~h}$ leading up to harvest. FDLE cultured under hormone-free conditions showed increases in REDD1 after 24 and $48 \mathrm{~h}$, which may have been because of cells achieving full confluence or because of the establishment of a fully polarized monolayer. This increase in REDD1 expression after $24 \mathrm{~h}$ was not mediated via MAPK pathways as REDD1 expression was not affected by the MAPK inhibitor SB203580 over the time course. Repression of REDD1 levels by DEX were apparent already after $2 \mathrm{~h}$ of treatment and maintained throughout the time course, indicating that DEX effects were not due to slowing of confluence. Fibroblast cultures showed little increase in REDD1 over time in culture under hormone-free media and in fact tended to decrease after $48 \mathrm{~h}$ suggesting that high cell density did not induce REDD1 in these cells. In contrast to FDLE, fetal lung fibroblasts do not exhibit contact inhibition, with multilayered growth creating thick stacks of alternate layers of cell. If up-regulation of REDD1 at high cell density is associated with contact inhibition, this might explain the differences in REDD1 mRNA time course in FDLE versus fibroblasts under hormone-free conditions. Similar to FDLE, DEX effects on REDD1 were significant within $2 \mathrm{~h}$ of initiating treatment and were maintained over $48 \mathrm{~h}$.

REDD1 mRNA stability in FDLE was significantly decreased by $50 \mathrm{nM}$ DEX treatment and this decrease of $\sim 40 \%$ is similar in magnitude to the drop in steady-state REDD1 mRNA level. This indicates that DEX-mediated regulation of REDD1 mRNA was post-transcriptional in these cells. Steroid hormones have been shown to regulate gene expression post-transcriptionally by altering mRNA stability of numerous targets, including GCmediated regulation of growth hormone, fatty acid synthetase, inflammatory response proteins, collagenase, and cyclin D3 (28). The stability of REDD1 mRNA in fibroblasts was unchanged by DEX, confirming a transcriptional up-regulation as initially reported in lymphoid cells (12).

The lack of induction of REDD1 by DEX in both FDLE and ATII cells is of particular interest in light of the use of glucocor- ticosteroid treatments antenatally to accelerate fetal lung maturation (3) and postnatally in preterm infants to prevent chronic lung disease (29). Routine use of systemic DEX in premature infants is not recommended because of concerns about negative side effects including abnormal neurologic development and reduced somatic growth, yet such use continues (30). Assuming that REDD1 induction and ensuing down-regulation of mTORdependent protein synthetic pathways would hold negative consequences for most tissues in light of the rapid growth and development occurring in the neonatal period, one could speculate that lung epithelia may escape negative effects of DEX treatment by this adaptation whereas other tissues do not. Clinical studies attempting to use inhaled corticosteroids in neonates at risk of chronic lung disease have so far been disappointing, but it is unclear whether this is due to the lung disease itself or the unique physiologic, anatomic, and technical issues involved in delivering inhaled drugs to the very low birth weight, ventilated infant (31). In light of the potentially specific effects of DEX on REDD1 in lung epithelial tissues, it appears worthwhile to continue to pursue attempts to optimize drug delivery via the inhaled route.

In summary, regulation of the cell signaling pathways mediated by REDD1 in response to both hypoxia and GC shows considerable evidence for cell-specific effects. Primary cultures of rat FDLE and fetal lung fibroblasts show no effect of changes between $21 \%$ and $3 \% \mathrm{O}_{2}$ on REDD1, and respond to DEX in opposite ways. These responses may be because of the adaptation of these cells to the fetal environment and an understanding of such pathways is potentially important in view of the use of antenatal glucocorticoids and controlled $\mathrm{O}_{2}$ ventilation in premature infants.

\section{REFERENCES}

1. Menconi M, Fareed M, O’Neal P, Poylin V, Wei W, Hasselgren PO 2007 Role of glucocorticoids in the molecular regulation of muscle wasting. Crit Care Med 35:S602-S608

2. Fussell JC, Kelly FJ 1991 Effects of dexamethasone on lung protein turnover. Biochem J 273:93-97

3. Jobe AH, Soll RF 2004 Choice and dose of corticosteroid for antenatal treatments. Am J Obstet Gynecol 190:878-881

4. Sin DD, Man SF 2006 Corticosteroids and adrenoceptor agonists: the compliments for combination therapy in chronic airways diseases. Eur J Pharmacol 533:28-35

5. Bream-Rouwenhorst HR, Beltz EA, Ross MB, Moores KG 2008 Recent developments in the management of acute respiratory distress syndrome in adults. Am J Health Syst Pharm 65:29-36

6. Stellato C 2004 Post-transcriptional and nongenomic effects of glucocorticoids. Proc Am Thorac Soc 1:255-263

7. Long W, Wei L, Barrett EJ 2001 Dexamethasone inhibits the stimulation of muscle protein synthesis and PHAS-I and p70 S6-kinase phosphorylation. Am J Physiol Endocrinol Metab 280:E570-E575

8. Martin DE, Hall MN 2005 The expanding TOR signaling network. Curr Opin Cell Biol 17:158-166

9. Corradetti MN, Inoki K, Guan KL 2005 The stress-inducted proteins RTP801 and RTP801L are negative regulators of the mammalian target of rapamycin pathway. J Biol Chem 280:9769-9772

10. Wang H, Kubica N, Ellisen LW, Jefferson LS, Kimball SR 2006 Dexamethasone represses signaling through the mammalian target of rapamycin in muscle cells by enhancing expression of REDD1. J Biol Chem 281:39128-39134

11. Brugarolas J, Lei K, Hurley RL, Manning BD, Reiling JH, Hafen E, Witters LA, Ellisen LW, Kaelin WG Jr 2004 Regulation of mTOR function in response to hypoxia by REDD1 and the TSC1/TSC2 tumor suppressor complex. Genes Dev 18:2893-2904

12. Wang Z, Malone MH, Thomenius MJ, Zhong F, Xu F, Distelhorst CW 2003 Dexamethasone-induced gene 2 (dig2) is a novel pro-survival stress gene induced rapidly by diverse apoptotic signals. J Biol Chem 278:27053-27058

13. Schwarzer R, Tondera D, Arnold W, Giese K, Klippel A, Kaufmann J 2005 REDD1 integrates hypoxia-mediated survival signaling downstream of phosphatidylinositol 3-kinase. Oncogene 24:1138-1149 
14. Shoshani T, Faerman A, Mett I, Zelin E, Tenne T, Gorodin S, Moshel Y, Elbaz S, Budanov A, Chajut A, Kalinski H, Kamer I, Rozen A, Mor O, Keshet E, Leshkowitz D, Einat P, Skaliter R, Feinstein E 2002 Identification of a novel hypoxia-inducible factor 1-responsive gene, RTP801, involved in apoptosis. Mol Cell Biol 22:22832293

15. Bolt RJ, van Weissenbruch MM, Lafeber HN, Delemarre-van de Waal HA 2001 Glucocorticoids and lung development in the fetus and preterm infant. Pediatr Pulmonol 32:76-91

16. Olver RE, Walters DV, Wilson M 2004 Developmental regulation of lung liquid transport. Annu Rev Physiol 66:77-101

17. Otulakowski G, Duan W, Gandhi S, O'Brodovich H 2007 Steroid and oxygen effects on eIF4F complex, mTOR, and ENaC translation in fetal lung epithelia. Am J Respir Cell Mol Biol 37:457-466

18. Kassel O, Herrlich P 2007 Crosstalk between the glucocorticoid receptor and other transcription factors: Molecular aspects. Mol Cell Endocrinol 275:13-29

19. Rafii B, Gillie DJ, Sulowski C, Hannam V, Cheung T, Otulakowski G, Barker PM, O'Brodovich H 2002 Pulmonary oedema fluid induces non-alpha-ENaC-dependent $\mathrm{Na}(+)$ transport and fluid absorption in the distal lung. J Physiol 544:537-548

20. Gandhi SG, Rafii B, Harris MS, Garces A, Mahuran D, Chen XJ, Bao HF, Jain L, Eaton DC, Otulakowski G, O'Brodovich H 2007 Effects of cardiogenic edema fluid on ion and fluid transport in the adult lung. Am J Physiol Lung Cell Mol Physiol 293:L651-L659

21. Jin HO, An S, Lee HC, Woo SH, Seo SK, Choe TB, Yoo DH, Lee SB, Um HD, Lee SJ, Park MJ, Kim JI, Hong SI, Rhee CH, Park IC 2007 Hypoxic condition- and high cell density-induced expression of Redd1 is regulated by activation of hypoxiainducible factor-1alpha and Sp1 through the phosphatidylinositol 3-kinase/Akt signaling pathway. Cell Signal 19:1393-1403

22. Kassel O, Sancono A, Kratzschmar J, Kreft B, Stassen M, Cato AC 2001 Glucocorticoids inhibit MAP kinase via increased expression and decreased degradation of MKP-1. EMBO J 20:7108-7116
23. Deleault KM, Skinner SJ, Brooks SA 2008 Tristetraprolin regulates TNF TNF-alpha mRNA stability via a proteasome dependent mechanism involving the combined action of the ERK and p38 pathways. Mol Immunol 45:13-24

24. Haddad JJ, Land SC 2000 O2-evoked regulation of HIF-1alpha and NF-kappa B in perinatal lung epithelium requires glutathione biosynthesis. Am J Physiol Lung Cell Mol Physiol 278:L492-L503

25. Land SC, Wilson SM 2005 Redox regulation of lung development and perinatal lung epithelial function. Antioxid Redox Signal 7:92-107

26. Koritzinsky M, Magagnin MG, van den Beucken T, Seigneuric R, Savelkouls K, Dostie J, Pyronnet S, Kaufman RJ, Weppler SA, Voncken JW, Lambin P, Koumenis C, Sonenberg N, Wouters BG 2006 Gene expression during acute and prolonged hypoxia is regulated by distinct mechanisms of translational control. EMBO J 25:1114-1125

27. Kimball SR, Do AN, Kutzler L, Cavener DR, Jefferson LS 2008 Rapid turnover of the mTOR complex 1 (mTORC1) repressor REDD1 and activation of mTORC1 signaling following inhibition of protein synthesis. J Biol Chem 283:3465-3475

28. Ing NH 2005 Steroid hormones regulate gene expression posttranscriptionally by altering the stabilities of messenger RNAs. Biol Reprod 72:1290-1296

29. Shinwell ES, Lerner-Geva L, Lusky A, Reichman B 2007 Less postnatal steroids, more bronchopulmonary dysplasia: a population-based study in very low birthweight infants. Arch Dis Child Fetal Neonatal Ed 92:F30-F33

30. Onland W, De Jaegere AP, Offringa M, van Kaam AH 2008 Effects of higher versus lower dexamethasone doses on pulmonary and neurodevelopmental sequelae in preterm infants at risk for chronic lung disease: a meta-analysis. Pediatrics 122:92 101

31. Dubus JC, Montharu J, Vecellio L, De MM, De MA, Goucher A, Cantagrel S, Le PA, Mezzi K, Majoral C, Le GS, Diot P 2007 Lung deposition of HFA beclomethasone dipropionate in an animal model of bronchopulmonary dysplasia. Pediatr Res 61:21-25 